\title{
THE EFFECT OF METHOXYFLURANE ON CEREBRAL BLOOD FLOW
} IN THE DOG

\author{
Iain G. Gray, Samir K. Mitra, Hugh I. A. Nisbet, Norman Aspin, and Robert E. \\ Creighton With the techNicAl help of George Volgyesi
}

IN NEUROSURGICAL ANAESTHESIA, there is a place for a volatile agent which will cause neither a significant rise in cerebral blood flow (CBF) nor an increase in intracranial pressure. Most inhalational agents in concentrations greater than 1 MAC increase both cerebral blood flow and intracranial pressure. ${ }^{1-\tau}$

Of the agents whose effects have been reported, methoxyflurane in low concentration appears to cause the least rise in cerebro-spinal fluid (CSF) pressure in patients undergoing neurosurgical procedures, whether or not a space-occupying lesion exists. Fitch ${ }^{8}$ showed that methoxyflurane $(0.5$ per cent inhaled concentration) caused an insignificant change in CSF pressure in patients with normal CSF pathways and only a small rise in those with a space occupying lesion.

Wollman et al. ${ }^{\text {}}$ found that with cyclopropane and diethyl ether cerebral blood flow in man was decreased during light anaesthesia and that cerebral perfusion increased as anaesthesia was deepened. The explosive risk limits the usefulness of these agents in neurosurgery. Since a non-explosive agent which produces little change in CSF pressure and CBF might have considerable clinical advantages, the effects of light methoxyflurane anaesthesia on CBF were studied in dogs.

\section{Methods and Materials}

Measurements of CBF were made in 11 Beagle dogs ranging in weight from 9-15 Kg. Anaesthesia was induced with pentobarbitone sodium, $30 \mathrm{mg} / \mathrm{Kg}$ intravenously and a cuffed endotracheal tube was inserted.

The vertebral artery was cannulated through a femoral artery using the Seldinger technique. Catheters were inserted into the right atrium through a femoral vein and into the aorta through the femoral artery. The latter was connected to a threeway tap to allow for withdrawal of arterial samples for blood gas estimation, continuous measurement of aortic blood pressure by a Bell and Howell transducer and measurement of cardiac output by a Waters' cuvette and densitometer, cardiogreen being used as the indicator. The dogs were placed on a heated blanket and given succinylcholine $(1.5 \mathrm{mg} / \mathrm{kg})$ intravenously.

They were ventilated with air by a Harvard animal respiratory pump set to deliver $200 \mathrm{ml}$ per stroke, the rate being adjusted to maintain a steady end-tidal $\mathrm{PCO}_{2}$ (measured with a Beckman $\mathrm{LBl}$ infra-red $\mathrm{CO}_{2}$ analyser). A non-rebreathing circuit was employed to reduce recirculation of ${ }^{133} \mathrm{Xe}$ and room background activity was kept at a minimum by venting all expired gases to the exterior of the room.

From the Research Institute, The Hospital for Sick Children and Departments of Anaesthesia, Paediatrics and Medical Biophysics, University of Toronto.

Canad. Anaesth. Soc. J., vol. 18, no. 4, July 1971 


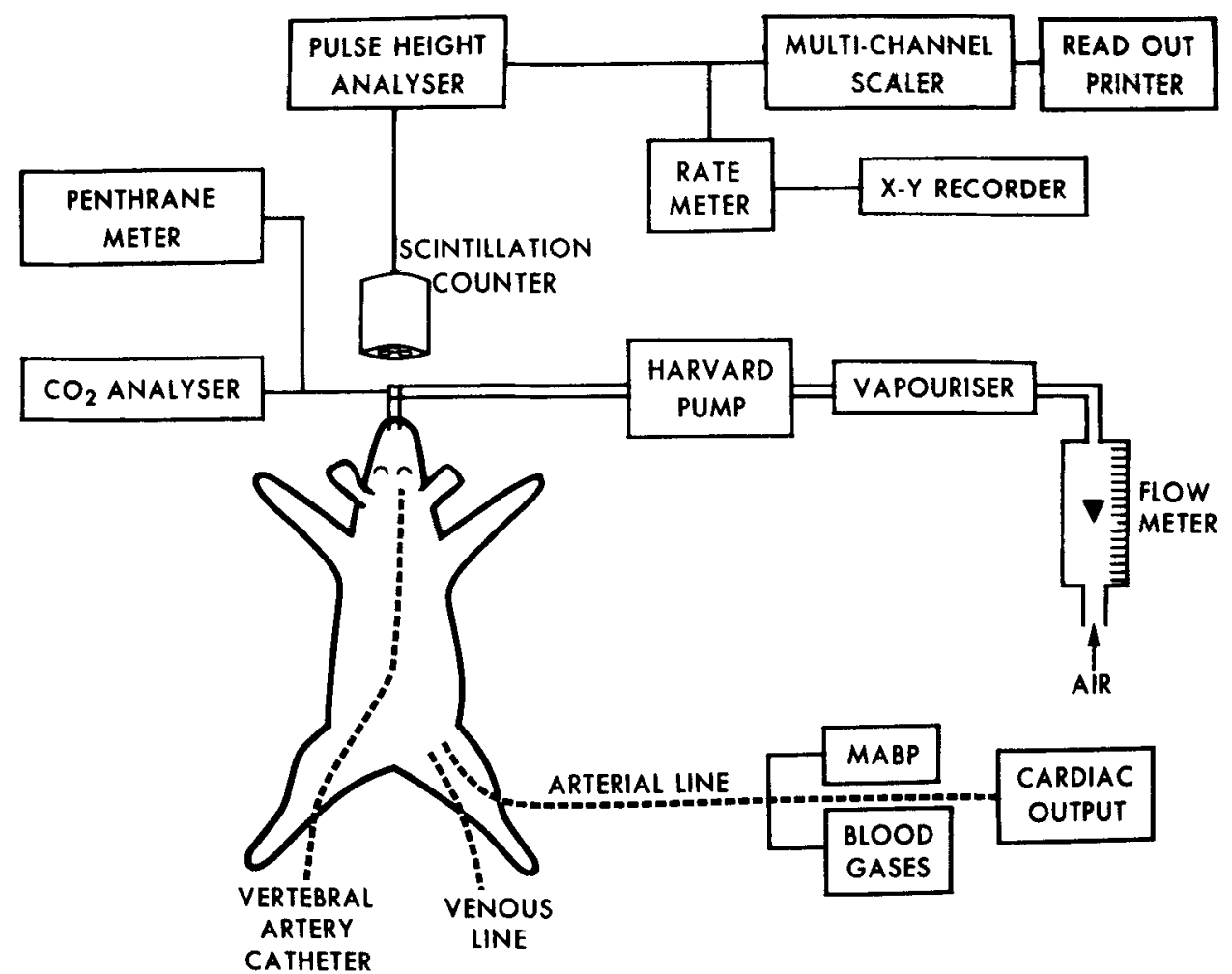

FICURE 1. Schematic representation of the anaesthetic circuit and apparatus.

Cerebral blood flow was determined by measuring the clearance of an arterially injected bolus of ${ }^{133} \mathrm{Xe}$ by means of a collimated scintillation probe positioned over the skull so as not to see the radioactivity in the airway. This method was first described for use with the beta emitting radio-nuclide ${ }^{85} \mathrm{Kr}$ by Ingvar and Lassen ${ }^{10}$ and adapted by Glass and Harper ${ }^{11}$ for external gamma ray detection of ${ }^{133} \mathrm{Xe}$ through the intact skull. (The experimental arrangement is shown schematically in Figure 1.)

One millicurie of ${ }^{133} \mathrm{Xe}$, dissolved in $2 \mathrm{ml}$ saline, was injected into the catheter in the vertebral artery, which was immediately flushed with $2 \mathrm{ml}$ of saline. The appearance and clearance of the radio-nuclide in the cerebral cortex was detected by means of the collimated scintillation probe which was connected through a pulse height analyser to an analogue rate-meter, the output of which was displayed on an X-Y recorder. A 4081 channel scalcr, operating as a digital rate-meter, was connected in parallel with the rate-meter in order to determine the effect on the calculated CBF of rate-meter time constant. During the first two minutes of measurement the analogue and digital rate-meter had time constant of 1.0 and 0.4 seconds respectively. During the remaining eight minutes of measurement the rate-meter time constants were increased to 4.0 and 0.6 seconds. The pulse-height analyser was set on the $81 \mathrm{Kev}$ gamma ray photopeak of ${ }^{133} \mathrm{Xe}$ to reduce the effect of scattered radiation. 
Cerebral blood flow was calculated from the count rate curves using the stochastic method of analysis described by Zierler ${ }^{12}$ and modified by Høedt-Rasmussen. ${ }^{13}$ The latter author avoided the problems inherent in measuring the count rate in the long tail of the washout curve by limiting the measurements to the 10 minutes following the injection of ${ }^{133} \mathrm{Xe}$. The CBF was calculated from the following formula:

$$
f=\frac{\lambda\left(H_{\max }-H_{10}\right) \times 100}{A_{10}}
$$

$$
\text { where } \begin{aligned}
\mathrm{f} & =\text { cerebral blood flow in } \mathrm{ml} / 100 \mathrm{~g} / \mathrm{min} \\
\lambda & =\text { blood brain partition coefficient for } \mathrm{Xenon}^{14} \\
\mathrm{H}_{\max } & =\text { maximum count rate } \\
\mathrm{H}_{10} & =\text { count rate } 10 \text { minutes post injection } \\
\mathrm{A}_{10} & =\text { area under count rate curve from } 0 \text { to } 10 \text { minutes }
\end{aligned}
$$

Cardiac output was measured before and after each injection and arterial blood samples analysed at regular intervals for $\mathrm{pH}, \mathrm{PCO}_{2}$ and $\mathrm{PO}_{2}$. EEG and temperature were monitored throughout and the blood gas results were corrected for temperature change.

After obtaining satisfactory radioactivity curves breathing air, methoxyflurane, vapourised in a calibrated Pentec ${ }^{\circledR}$ vapouriser, was added to the inspired gases and administration was continued for 30 minutes, end-tidal methoxyflurane being monitored in each case. In 7 dogs, end-tidal methoxyflurane was close to 0.3 per cent and in 4 dogs it was approximately 0.6 per cent. Cardiac output and arterial blood gases were recorded throughout and at the end of the 30 minute period, CBF was again measured.

\section{RESULTS}

The results of all measurements are shown in Tables I to VI. Tables I and III list measurements of $\mathrm{CBF}$, blood gas tensions, $\mathrm{pH}$, mean arterial blood pressure (MABP), cardiac output, and deep body temperature in the dogs anaesthetised

\begin{tabular}{|c|c|c|c|c|c|c|c|}
\hline $\begin{array}{l}\text { Dog. } \\
\text { No. }\end{array}$ & $\begin{array}{c}\mathrm{CBF} \\
(\mathrm{ml} / 100 \mathrm{~g} / \mathrm{min})\end{array}$ & $\begin{array}{c}\mathrm{PaCO}_{2} \\
(\mathrm{~mm} \mathrm{Hg})\end{array}$ & $\frac{\mathrm{PaO}_{2}}{(\mathrm{~mm} \mathrm{Hg})}$ & $\mathrm{pH}$ & $(\mathrm{L} / \mathrm{Q} \min )$ & $\begin{array}{c}\text { MABP } \\
(\mathrm{mm} \mathrm{Hg})\end{array}$ & $\underset{{ }^{\circ} \mathrm{C}}{\text { Temp }}$ \\
\hline 1 & 42 & 36 & 78 & 7.30 & 1.6 & 100 & 35 \\
\hline 2 & 41 & 35 & 70 & 7.36 & 1.5 & 100 & 35 \\
\hline 3 & 51 & 36 & 66 & 7.37 & 2.1 & 120 & 35 \\
\hline 4 & 41 & 33 & 84 & 7.36 & 2.8 & 116 & 35 \\
\hline 5 & 34 & 35 & 97 & 7.35 & 2.3 & 85 & 35 \\
\hline 6 & 33 & 35 & 78 & 7.34 & 2.15 & 115 & 36 \\
\hline 7 & 30 & 38 & 102 & 7.32 & 2.4 & 125 & 36 \\
\hline Mean & 38.9 & 34.7 & 78 & 7.34 & 2.12 & 109 & 35.3 \\
\hline SD & \pm 6.5 & \pm 1.4 & \pm 12.3 & \pm 0.025 & \pm 0.42 & \pm 13 & \pm 0.4 \\
\hline
\end{tabular}
with pentobarbitone. Tables II and IV show the subsequent values of these parameters in the same dogs under end-tidal concentrations of methoxyflurane of 0.31 and 0.605 per cent respectively, while Tables $\mathrm{V}$ and VI list the change in mean

TABLE I

Cerebral Blood Flow During Pentobarbitone/Air Anaesthesia 


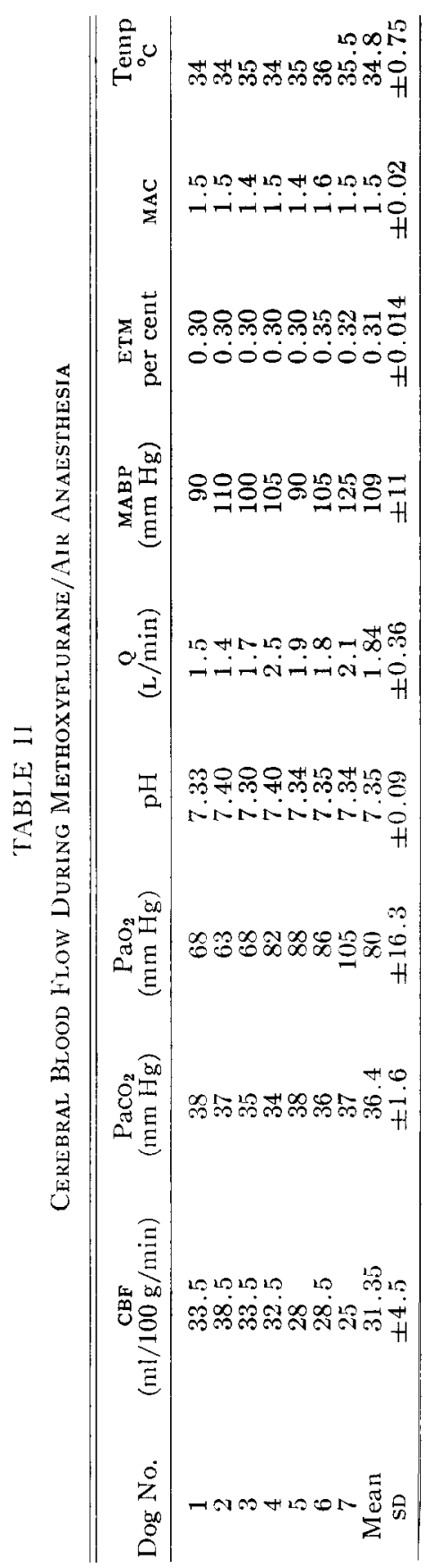


TABLE III

Cerebral Blood Flow During Pentobarbitone/air Anaesthesta

\begin{tabular}{cccccccc}
\hline \hline $\begin{array}{c}\text { Dog } \\
\text { No. }\end{array}$ & $\begin{array}{c}\mathrm{CBF} \\
(\mathrm{m} / 100 \mathrm{~g} / \mathrm{min})\end{array}$ & $\begin{array}{c}\mathrm{PaCO}_{2} \\
(\mathrm{~mm} \mathrm{Hg})\end{array}$ & $\begin{array}{c}\mathrm{PaO}_{2} \\
(\mathrm{~mm} \mathrm{Hg})\end{array}$ & $\mathrm{pH}$ & $\begin{array}{c}{ }^{\mathrm{Q}} \\
(\mathrm{Lin} / \mathrm{min})\end{array}$ & $\begin{array}{c}\mathrm{MABP} \\
(\mathrm{mm} \mathrm{Hg})\end{array}$ & $\begin{array}{c}\text { Temp } \\
{ }^{\circ} \mathrm{C}\end{array}$ \\
\hline 8 & 41 & 34 & 86 & 7.34 & 1.50 & 105 & 34 \\
9 & 42 & 33 & 88 & 7.32 & 1.90 & 90 & 35 \\
10 & 46 & 36 & 90 & 7.34 & 1.70 & 115 & 35 \\
11 & 36 & 33 & 83 & 7.42 & 1.65 & 100 & 35 \\
Mean & 40.7 & 34 & 87 & 7.35 & 1.7 & 103 & 34.8 \\
SD & \pm 2.7 & \pm 1.2 & \pm 2.6 & \pm 0.08 & \pm 0.15 & \pm 9 & \pm 0.15 \\
\hline
\end{tabular}

values of $\mathrm{CBF}$, cardiac output, MABP, and $\mathrm{PaCO}_{2}$, together with the significance of these changes under the different anaesthetic conditions.

Under pentobarbitone anaesthesia, the mean values for cerebral blood flow were $38.9 \mathrm{ml} / 100 \mathrm{~g} / \mathrm{min}$ in the 7 dogs later studied with the lower methoxyflurane concentration (Table I); $40.7 \mathrm{ml} / 100 \mathrm{~g} / \mathrm{min}$ in the 4 dogs who were subsequently given the higher concentration of methoxyflurane (Table III); and $39.7 \mathrm{ml} / 100$ $\mathrm{g} / \mathrm{min}$ in the combined groups.

In the seven dogs studied at end-tidal methoxyflurane concentrations of 0.31 per cent, equivalent to $1.5 \mathrm{MAC}$ at $35^{\circ} \mathrm{C}^{15}$ the cerebral blood flow fell from 38.9 $\mathrm{ml} / 100 \mathrm{~g} / \mathrm{min}$ under pentobarbitone anaesthesia to $31.3 \mathrm{ml} / 100 \mathrm{~g} / \mathrm{min}$ (Table V) during methoxyflurane and the mean arterial carbon dioxide tension $\left(\mathrm{PaCO}_{2}\right)$ rose from $34.7 \mathrm{~mm} \mathrm{Hg}$ to $36.4 \mathrm{~mm} \mathrm{Hg}$. The mean arterial oxygen tension $\left(\mathrm{PaO}_{2}\right)$ and $\mathrm{pH}$ under methoxyflurane did not change significantly from the values measured under pentobarbitone. Although cardiac output fell from $2.12 \mathrm{~L} / \mathrm{min}$ to $1.84 \mathrm{~L} / \mathrm{min}$, no change occurred in mean aortic blood pressure (MABP) during the period of investigation. The rectal temperature fell slightly during measurements under methoxyflurane.

In the 4 dogs studied at 0.61 per cent end-tidal methoxyflurane equivalent to $3.1 \mathrm{MAC}$ at $34^{\circ} \mathrm{C}$, cerebral blood flow fell from $40.7 \mathrm{ml} / 100 \mathrm{~g} / \mathrm{min}$ during pentobarbitone anaesthesia to $34.4 \mathrm{ml} / 100 \mathrm{~g} / \mathrm{min}$ under methoxyflurane. $\mathrm{PaCO}_{2}$ rose from $34 \mathrm{~mm} \mathrm{Hg}$ to $35 \mathrm{~mm} \mathrm{Hg}$, MABp fell from $103 \mathrm{~mm} \mathrm{Hg}$ to $79 \mathrm{~mm} \mathrm{Hg}$ and $\mathrm{PaO}_{2}$ fell from $87 \mathrm{~mm} \mathrm{Hg}$ to $75 \mathrm{~mm} \mathrm{Hg}$. A small fall in temperature occurred during the period of investigation and cardiac output was slightly decreased under methoxyflurane. There was no significant change in arterial $\mathrm{pH}$ during these investigations.

\section{Discussion}

\section{Technique}

In most previous measurements of cerebral blood flow in the dog, radio-nuclides have been infused or injected into the carotid artery. This is acceptable when the scintillation counters are placed upon exposed cortex, but when external counting is used as in the present report, the considerable distribution of the dog's internal carotid arterial system to extracerebral tissues creates difficulties. ${ }^{16}$

For this reason, angiographic studies were made of the vascular distribution from the dog's vertebral artery. Radio opaque material was found to be distributed 


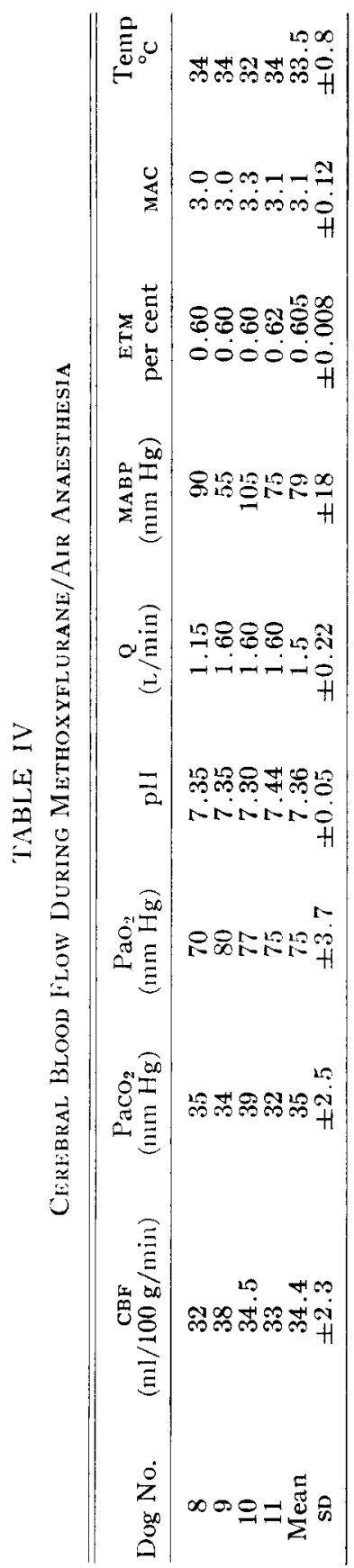


TABLE V

Changes in Cerebral Blood Flow (cbF) Cardiac Output (co) Mean Arterial Blood Pressure (MabP) and ARterial $\mathrm{PCO}_{2}$ DURing Anaesthesia with 0.3 MethoXYFluRANe

\begin{tabular}{lcccc}
\hline \hline & $\mathrm{CBF}$ & $\mathrm{CO}$ & $\mathrm{MABP}$ & $\mathrm{PCO}_{2}$ \\
\cline { 2 - 5 } Pentobarbitone/air & $38.9 \pm 6.5$ & $2.12 \pm 0.42$ & $109 \pm 13$ & $34.7 \pm 1.4$ \\
Methoxyflurane/air & & & & \\
$\quad 0.3$ per cent & $31.3 \pm 4.5$ & $1.84 \pm 0.36$ & $109 \pm 1$ & $34.6 \pm 1.6$ \\
Significance & $p<0.01$ & $p>0.1$ & $p>0.1$ & $p>0.1$ \\
\hline
\end{tabular}

TABLE VI

Changes in Cerebral Blood Flow (cbi) Cardiac Output (co) Mean Arterial Blood Pressure (Mabp) and ARTerial $\mathrm{PCO}_{2}$ DURing ANaesthesia with 0.6 MethoXYFLURANE

\begin{tabular}{lcccc}
\hline \hline & CBF & Co & MABP & $\mathrm{PCO}_{2}$ \\
\cline { 2 - 5 } & $40.7 \pm 2.7$ & $1.7 \pm 0.15$ & $103 \pm 9$ & $34 \pm 1.2$ \\
Pentobarbitone/air & & & & \\
Methoxyflurane/air & & & \\
$\quad 0.6$ per cent & $34.4 \pm 2.3$ & $1.5 \pm 0.22$ & $79 \pm 18$ & $35 \pm 2.5$ \\
Significance & $p<0.05$ & $p>0.1$ & $p>0.1$ & $p>0.1$ \\
\hline
\end{tabular}

almost entirely inside the cranium when the catheter was placed close to the base of the skull and this artery was used for injection throughout this series.

The clearance curves were analysed by the non-compartmental or stochastic method ${ }^{12,13}$ which reveals the mean blood flow through the area of tissue seen by the scintillation counter. McHendry et $a l .{ }^{16}$ and Høedt-Rasmussen et al. ${ }^{13}$ found that repeated stochastic analysis gave reproducible results which correlated well $(r=0.9)$ with values obtained both by a modified Kety-Schmidt technique and two-compartmental analysis. Zierler ${ }^{12}$ showed that agreement between stochastic and compartmental methods of analysis is fortuitous and that the stochastic method of analysis is to be preferred. Oeconomos ${ }^{17}$ discussed the difficulties of compartmental analysis, its dependence on the shape of the clearance curve and the importance of the ratio of maximum activity to background count. Since certain curves are difficult to calculate with any degree of accuracy ${ }^{17}$ especially if exponential curve fitting is done graphically ${ }^{18}$ compartmental analysis was not undertaken in this series.

Measurement of cerebral blood flow by stochastic analysis depends on the accurate determination of both the peak height and the area under the clearance curve. To measure peak height, Potchen et al..$^{19}$ have suggested that a time constant of 0.4 seconds is required. In the present study, the peak heights calculated from the rate-meter (time constant 1 second) and from the digital print out (time constant 0.4 or 0.6 second) were the same.

Xenon washout from cerebral tissues is very slow, so that very lengthy measurements are required to determine the total area under the washout curve. Some authors ${ }^{13}$ suggest fitting a single exponential function to the tail of the washout curve in order to shorten the measurement time and yet obtain the total area under 
the curve. This approach is very subjective and prone to error. For this reason, the analysis was performed on measurements of the washout curve in the 10 minutes following the injection of the ${ }^{133} \mathrm{Xe}$ bolus. ${ }^{13}$

The ratio of total integrated counts over ten minutes to background activity also affects the results. Greater correlation is obtained with other methods of analysis if this index is high (over 20:1) ${ }^{17}$ For this reason care was taken to allow background activity to return to pre-injection levels between each measurement.

\section{Results}

During barbiturate anaesthesia, cerebral blood flow and metabolic rate are reduced in proportion to the depth of anaesthesia. ${ }^{3}$ The mean value of $39.7 \mathrm{ml} / 100$ $\mathrm{g} / \mathrm{min}(\mathrm{SD} \pm 5.7$ ) found in the present series under pentobarbitone agrees fairly closely with those previously reported. Cohen $e t$ al. ${ }^{25}$ reported a mean value of $44.1 \mathrm{ml} / 100 \mathrm{~g} / \mathrm{min}$ in lightly anaesthetised man and Haggendal and Johanssen ${ }^{20}$ who also used the vertebral artery for the tracer injection, reported a mean value of $60 \mathrm{ml} / 100 \mathrm{~g} / \mathrm{min}$ for cerebral grey matter in dogs under pentobarbitone anaesthesia. When correction is made for the higher flow rate in grey matter compared to total cortex, and the fact that compartmental analysis tends to give slightly higher values for flow than stochastic analysis, ${ }^{13}$ there is little difference in the values between the two series.

Pentobarbitone anaesthesia was deepest during the cannulation procedures and gradually lightened so that the control measurements were made while the dog was in a state of deep sedation, at which level values for cerebral blood flow are not very different from those in the conscious state. ${ }^{21}$

Inhalation of methoxyflurane in concentrations sufficient to produce end-tidal levels of 0.3 per cent (equivalent to $1.5 \mathrm{MAC}$ ) reduced the cerebral blood flow by 20 per cent $(p<0.01)$ from the sedated level.

This fall in $\mathrm{CBF}$ is consistent with the lack of a significant rise in CSF pressure reported by Fitch $^{8}$ during light methoxyflurane anaesthesia in man. Wollman et al. ${ }^{9}$ found a similar fall in CBF for an equivalent depth of anaesthesia under cyclopropane.

Methoxyflurane in the higher concentration ( $3 \mathrm{MAC}$ ) did not produce so great or so significant $(p<0.05)$ a fall in CBF. This is consistent with the hypothesis of Wollman et al." that cerebral flow decreases under light anaesthesia and increases as anaesthesia deepens.

The small changes in $\mathrm{PaCO}_{2}$ during these experiments are unlikely to have influenced the results. Mean $\mathrm{PaCO}_{2}$ under methoxyflurane was $1.2 \mathrm{~mm} \mathrm{Hg}$ higher than under pentobarbitone, but this would tend to increase rather than reduce cerebral blood flow as would the lower $\mathrm{PaO}_{2}$. McDowell ${ }^{22}$ has shown that a severe fall in $\mathrm{PaO}_{2}$ is required to increase $\mathrm{CBF}$ significantly.

The fall in MABP under methoxyflurane was not of such severity as to impair the autoregulatory mechanism..$^{23}$ The fall in cardiac output during methoxyflurane was not significant $(p>0.1)$ and it is unlikely to have had any effect on cerebral perfusion since $\mathrm{MABP}$ was not significantly altered.

Rosomoff ${ }^{24}$ found that CBF falls by 6-7 per cent per degree centigrade decline in temperature. The mean recorded fall of $1.3^{\circ} \mathrm{C}$ in the group receiving 0.6 per cent 
methoxyflurane could therefore explain only a small part of the total reduction in cerebral perfusion.

\section{Conclusion}

In dogs under barbiturate anaesthesia CBF is significantly reduced by methoxyflurane in concentration of $1.5 \mathrm{MAC}$ and less significantly by $3.0 \mathrm{MAC}$. Since low concentrations of this agent do not significantly raise CSF pressure in man, it is concluded that this agent may be particularly suitable for clinical use during neurosurgical anaesthesia.

\section{RÉSUMÉ}

Onze chiens ont été anesthésiés au pentobarbitone $(30 \mathrm{mg} / \mathrm{kg})$, intubés et ventilés avec de l'air de façon à maintenir constante la concentration de dioxide de carbone en fin d'expiration. Nous avons inséré des cathéters dans l'oreillette droite et dans l'aorte pour la mesure du débit cardiaque, des gaz sanguins et de la pression artérielle. A travers une artère fémorale, nous avons cannulé une artère vertébrale sous fluoroscopie et ce fut la voie utilisée pour linjection du $\mathrm{Xe}^{133}$. Nous avons établi le débit cérébral (CBF) en mesurant la vitesse de clearance du bolus de $\mathrm{Xe}^{133}$ injecté dans l'artère en employant la technique de détection externe aux rayons gamma à travers la boîte cranienne intacte et le CBF a été calculé d'après les courbes de comptage pour analyse stochastique. Le débit cardiaque a été mesuré avant et après chacune des injections. La pression artérielle, les gaz sanguins, l'EEG et la température ont été enregistrés durant toute l'expérience.

Après avoir obtenu des courbes de radioactivité satisfaisantes sur l'air, le procédé était répété après avoir ajouté du méthoxyflurane à l'air inspiré aux concentrations de 0.3 et de 0.6 pour cent à la fin de l'expiration et, cela, durant 30 minutes.

Sous anesthésie au pentobarbitone, le débit sanguin cérébral moyen était de $39.7 \mathrm{ml} / 100 \mathrm{~g} /$ minute. Avec le méthoxyflurane 0.31 pour cent à la fin de l'expitation ( $1.5 \mathrm{MAC}$ ) le débit cérébral était $31.3 \mathrm{ml} / 100 \mathrm{~g} /$ minute. Le débit cardiaque a également baissé de $2.121 /$ minute à $1.841 /$ minute. Les autres paramètres, à toute fin pratique, n'ont pas changé. Au pourcentage de 0.6 , fin d'expiration ( $3 \mathrm{MAC})$, le débit cérébral est tombé à une moyenne de $34.4 \mathrm{ml} / 100 \mathrm{~g} /$ minute. Il y avait une baisse de $30 \mathrm{~mm}$ de mercure de la pression artérielle, mais peu de changement du débit cardiaque.

\section{Conclusion}

Durant l'anesthésie au méthoxyflurane à des concentrations cliniques, le débit sanguin cérébral des chien est sensiblement plus bas que celui des animaux de contrôle sous anesthésie aux barbituriques. Etant donné qu'il est connu que les changements de pression du liquide CR sont minimes avec le méthoxyflurane, cet agent peut s'avérer très utile pour l'anesthésie en neurochirurgie.

\section{ACKNOWLEDGMENTS}

We are indebted to Dr. P. McDonald of the Department of Radiology, for his valuable assistance with the technique of vertebral artery cannulation and to Dr. 
E. Echevarre for his help with the surgery. We should also like to thank Dr. W. Zingg and his staff for the use of the facilities in the Animal Research Laboratories.

\section{REFERENCES}

1. McDowall, D. G.; Harper, A. M.; \& Jacobson, I. Cerebral blood flow during halothane anaesthesia. Brit. J. Anaesth., 35: 394 ( 1963 ).

2. McDowall, D. G.; Harper, A. M.; \& Jacobson, I. Cerebral blood flow during trichlorethylene anaesthesia; a comparison with Halothane. Brit. J. Anaesth., 36: 11 (1964).

3. MCDowall, D. G. The effects of general anaesthetics on cerebral blood flow and cerebral metabolism. Brit. J. Anaesth., 37: 236 (1965).

4. McDowall, D. G. \& HarPer, A. M. Blood flow and oxygen uptake of the cerebral cortex of the dog during anaesthesia with different volatile agents. Acta. Neurol. Scand. Suppl., 14: 146 (1965).

5. McDowall, D. G. Cerebral neurodynamics and metabolism during general anaesthesia. Acta. Anaesth. Scand. Suppl., 25: 307 (1966).

6. Wollman, H.; Alexander, S. C.; Cohen, P. J.; Chase, P. E.; Melman, E.; \& Behar, M. G. Cerebral circulation of man during halothane anaesthesia. Anaesthesiology, 25: 180 (1964).

7. Wollman, H.; Alexander, S. C.; Cohen, P. J.; Smith, T. C.; Chase, P. E.; \& Van der Molex; R. A. Cerebral circulation during anaesthesia and hyperventilation in man. Anaesthesiology, 26:329 (1965).

8. Frтch, W. in Cerebral Circulation, ed. McDowall, D. G. International Anaesthesiology Clinics, Boston: Little, Brown \& Co., Vol. 7 No. 3 (1969) p. 645.

9. Wollmax, H.; Smith, A. L.; \& Alexander, S. C. Effects of general anaesthetics in man on the ratio of cerebral blood flow to cerebral oxygen consumption. In: Cerebral Blood Flow. eds. Brock, M., Fieschi, C., Ingvar, D. H., Lassen, N. A., Schurmann, K. SpringerVerlag. Berlin (1969) p. 242.

10. Ingvar, D. H. \& Lassen, N. A. Regional blood flow of the cerebral cortex determined by Krypton 85. Acta. physiol. scandinav., 54: 325 (1962).

11. Glass, H. I. \& Harper, A. M. Measurement of regional blood flow in the cerebral cortex of man through the intact skull. Brit. M. J., $1: 593$ (1963).

12. ZiERLER, K. L. Equations for measuring blood flow by external monitoring of radioisotopes. Circulation Res., 16: 309 (1965).

13. Høedt-Rasmussen, K.; Sveinsdotrir, E.; \& Lassen, N. A. Regional blood flow in man determined by intra-arterial injection of radioactive inert gas. Circulation Res., 18: 237 (1966).

14. Veall, N. \& Mallet, B. L. The partition of trace amounts of Xenon between human blood and brain tissues at $37^{\circ} \mathrm{C}$. Phys. Med. Biol., 10:375 (1965).

15. Regan, M. J. \& EgER, E. I., II. Effect of hypothermia in dogs on anaesthetising and apnoeic doses of inhalation agents. Determination of the anaesthetic index. Anaesthesiology, 28: 689 (1967).

16. MCHenry, L. C. JR.; JAFFe, M. E.; \& Goldberg, H. I. Evaluation of the CBF method of Lassen and Ingvar in cerebral blood flow. ed. Brock, M., Fieschi, C., Ingvar, D. H., Lassen, N. A., Schurmann, K. Berlin: Springer-Verlag (1969) p. II.

17. Oeconomos, D. Stochastic analysis and slope determination of linear and semi logarithmic clearance curves respectively. Practical considerations. In: Cerebral Blood Flow. eds. Brock, M., Fieschi, C., Ingvar, D. H., Lassen, N. A., Schurmann, K. Springer-Verlag. Berlin (1969) p. 24.

18. McDowalt, D. G. Regional blood flow measurement in clinical practice. Brit. J. Anaesth., 41: 761 (1969).

19. Potchen, E. I.; Davis, D. O.; Whartan, T.; Hill, R.; \& Taveras, J. M. Regional cerebral blood flow in man. Arch. Neurol., 20:378 (1969).

20. Hagcendal, E. \& Johansson, B. Effects of arterial carbon dioxide tension and oxygen saturation on cerebral blood flow autoregulation in dogs. Acta. Physiol. Scand. Suppl., 258: 27 (1965).

21. KetY, S. S. in Circulation: Proceedings of the Harvey Tercentenary Congress Oxford: Blackwell ( 1958) p. 324.

22. MCDowal, D. G. Inter-relationships between blood oxygen tensions and cerebral blood flow: in Oxygen measurement in blood and tissues. ed. Payne, J. P. and Hill, D. W. Churchill: London (1966) p. 205. 
23. HAGGENDAL, E. Blood flow autoregulation of the cerebral grey matter with comments on its mechanism. Acta. Neurol. Scand. Suppl., 14: 104 (1965).

24. Rosemoff, H. L. Some effects of hypothermia on the normal and abnormal physiology of the nervous system. Proc. Roy. Soc. Med., 49: 358 ( 1956).

25. Cohen, P. J.; Alexander, S. C.; \& Wollman, H. Effects of hypocarbia and of hypoxia with normocarpia on cerebral blood flow and metabolism in man. Scand. J. Lab. and Clin. Invest. Suppl., 102 Iv: A (1968). 